\title{
Perbandingan Waktu Pemulihan Rumput Laut Kappaphycus alvarezii (Doty 1985) yang Mengalami Kerusakan Akibat Gigitan Ikan Herbivora yang Dipelihara dalam Jaring Kotak dan Dinding Jaring
}

\author{
[Comparison of Recovery Duration of Kappaphycus alvarezii, (Doty 1985) Seaweed \\ Deteriorated by Bites of Herbivorous Fish that Maintained in Box Net and Net Walls]
}

Dodi Efendi Buamona ${ }^{*}$, Indriyani Nur², Ma'ruf Kasim

\author{
${ }^{1,2}$ Program Studi Budidaya Perairan, Fakultas Perikanan dan Ilmu Kelautan Universitas Halu Oleo \\ ${ }^{3}$ Program Studi Manajemen Sumberdaya Perairan, Fakultas Perikanan dan Ilmu Kelautan Universitas Halu Oleo \\ Jl. HEA Mokodompit Kampus Bumi Tridharma Anduonohu Kendari, Indonesia 93232 \\ *Email korespondensi: dodiefendibuamona97@gmail.com
}

\begin{abstract}
Abstrak
Salah satu kendala budidaya rumput laut adalah tingginya pemangsaan hama, maka media yang digunakan diharapkan dapat meningkatkan produksi rumput laut. Penelitian ini bertujuan untuk membandingkan waktu pemulihan thallus rumput laut $K$. alvarezii yang mengalami kerusakan akibat gigitan ikan herbivora dan mengetahui laju pertumbuhan spesifik rumput laut yang dipelihara pada jaring kotak dan dinding jaring. Bibit thallus $K$. alvarezii, ditempatkan pada media jaring kotak dan dinding jaring dan dipelihara selama 2 bulan di perairan Pantai Lakeba Kota Bau-Bau. Parameter yang diamati adalah pemulihan thallus rumput laut, laju pertumbuhan spesifik, parameter kualitas air dan hubungan antara LPS dan parameter kualitas air. Hasil yang diperoleh pemulihan thallus rumput laut pada jaring kotak lebih cepat yaitu (11 hari) masa pemeliharaan dibandingkan dinding jaring yaitu (15 hari) masa pemeliharaan. LPS tertinggi pada jaring kotak yaitu pekan ke-1 sebesar 7,00\% dan terendah pekan ke-6 sebesar 3,13\% sedangkan LPS tertinggi pada dinding jaring yaitu pekan ke-1 sebesar $6,61 \%$ dan terendah pekan ke-6 sebesar $2.95 \%$. Hasil analisis menunjukan bahwa (LPS) berbeda nyata antara kedua perlakuan.
\end{abstract}

Kata Kunci: Kappaphycus alvarezii, pemulihan, pertumbuhan, jaring kotak, dinding jaring

\begin{abstract}
One of the obstacles in seaweed cultivation is the high rate of pest predation, by which the culture medium used are expected to increase seaweed production. The aims of this study were to compare the recovery duration for the thallus of Kappaphycus alvarezii damaged by the bite of herbivorous fish and to determine the specific growth rate of seaweed seedlings maintained in grid nets and net walls. The thallus of $K$. alvarezii were placed in grid nets and net walls and then maintained for 2 months in Lakeba Beach, Bau-Bau City. The parameters observed were the recovery duration of seaweed thallus, specific growth rate (SGR), water quality parameters and the correlation between SGR and water quality. the analysis used is to use the t-test with a confidence level of $95 \%$. The results obtained that the thallus recovery duration of seaweed in box nets is faster (11 days of maintenance) than the net walls ( 15 days of maintenance. The highest SGR in grid nets is the first week (7.00\%) and the lowest is the 6th week $(3.13 \%)$, while the highest SGR is in the netting wall, namely the first week $(6.61 \%)$ and the lowest in the 6th week $(2.95 \%)$. Based on the results of the test analysis using the t-test showed that the SGR was significantly different between the two treatments.
\end{abstract}

Keywords: Kappaphycus alvarezii, recovery, growth, grid nets, net walls.

\section{PENDAHULUAN}

Rumput laut merupakan salah satu produk perikanan yang memiliki potensi cukup besar untuk dikembangkan di Indonesia. Kappaphycus alvarezii atau Eucheuma cottonii merupakan jenis rumput laut yang dianggap mempunyai peluang besar untuk dikembangkan (Muklis dkk., 2016). Parenrengi dkk., (2010) menyatakan bahwa rumput laut $K$. alvarezii memiliki kandungan karaginan telah banyak dimanfaatkan sebagai bahan utama dalam industri makanan, kosmetik, farmasi dan pupuk organik.

Pertumbuhan rumput laut $K$. alvarezii dipengaruhi dua faktor yaitu faktor internal dan faktor eksternal. Faktor internal yang berpengaruh terhadap pertumbuhan rumput laut antara lain jenis, galur, bagian thallus dan umur. Sedangkan faktor eksternal yang berpengaruh antara lain lingkungan fisika dan kimiawi perairan (Kamlasi, 2008). Pertumbuhan alga berhubungan dengan proses pembentukan dan pembelahan sel pada thallus. Proses pembentukan thallus 
mempengaruhi metabolisme dinding sel dan pembentukan dinding sel yang meningkat, menyebabkan material penyusun dinding sel juga meningkat, peningkatan dinding sel akan meningkatkan kandungan karaginan ikut meningkat (Zainuddin dan Masyarul, 2018). Setiap jenis rumput laut membutuhkan kondisi lingkungan yang berbeda-beda. Daya dukung terhadap rumput laut tergantung pada lokasi, metode dan waktu tanam rumput laut (Winarno $d k k .$, 1996).

Rumput laut $K$. alvarezii umum digunakan masyarakat pesisir Indonesia, khususnya masyarakat petani rumput laut. Namun saat ini intensitas penyerangan terhadap rumput laut sering dilakukan oleh hama ikan herbivora. Penyerangan ikan herbivora telah menyebabkan luka pada thallus rumput laut dan dapat menurunkan produksi rumput laut hingga $60 \%$. Kerusakan thallus yang disebabkan akan memberi peluang recovery. Hal ini karena rumput laut adalah tumbuhan tingkat rendah yang akan melakukan recovery jika terjadi kerusakan thallus. Penelitian yang sangat dibutuhkan saat ini dalam upaya meningkatkan produksi rumput laut adalah dengan menggunakan media budidaya rumput laut yang terproteksi yang mampu melindungi rumput laut dari berbagai serangan hama ikan herbivora. Untuk mengetahui efektifitas media yang digunakan dalam budidaya rumput laut tersebut, maka perlu diketahui proses kepulihan rumput laut pasca gigitan ikan herbivora (ikan baronang) Siganus sp. dan faktor lingkungan yang mendukung pemulihan dan pertumbuhan rumput laut.

Budidaya rumput laut sering kali terserang oleh hama seperti ikan herbivora salah satunya yaitu (ikan baronang) Siganus sp. Ikan Baronang (Siganus sp) merupakan jenis ikan karang dari famili Siganidae termasuk ikan herbivora yang memiliki keanekaragaman spesies dan tersebar di berbagai wilayah perairan Indonesia (Sitepu $d k k$. , 2018). Selain memakan fitoplankton, ikan baronang juga memakan tumbuh- tumbuhan termasuk makroalga (alga merah), ganggang atau rumput laut (Selviani $d k k$., 2018) dan menjadimakanan favorit ikan baronang di alam (Faisal $d k k$., 2013). Gigitan ikan baronang dapat menyebabkan luka pada thallus rumput laut. Hal ini dapat ditanggulangi dengan pemakaian jaring untuk pengamanan rumput laut E. cottonii (Rejeki $d k k$. 2012). Berdasarkan hasil penelitian Reddy $d k k .$, (2007) yaitu kemunculan thallus baru setelah mengalami kerusakan terjadi pada masa pemeliharaan 10 hari.

Penelitian inimenggunakan media pemeliharaan berupa jaring kotak dan dinding jaring. Jaring kotak merupakan media budidaya yang membentuk kantung persegi empat memanjang secara horizontal dipermukaan laut, rangka utama dari pipa paralon dan kantong yang dimaksud terbuat dari jaring. Keunggulan media pemeliharaan jaring kotak yaitu rumput laut terlindungi dari serangan ikan herbivora karena merupakan wadah yang terproteksi, sehingga ikan pemakan rumput laut tidak dapat memakan rumput laut karena terhalang oleh jaring yang membentuk kantungan segi empat. Sedangkan keunggulan media dinding jaring yaitu rumput laut yang dibudidayakan bisa dalam jumlah yang lebih banyak tetapi tidak terproteksi. Tujuan penelitian ini adalah untuk membandingkan waktu pemulihan thallus rumput laut yang mengalami kerusakan akibat gigitan ikan herbivora pada jenis $K$. alvarezii dan mengetahui laju pertumbuhan spesifik dari bibit rumput laut yang dipelihara pada jaring kotak dan dinding jarring.

\section{METODE PENELITIAN}

Penelitian dilakukan pada bulan November-Desember 2019. Bertempat di perairan pantai Lakeba Kota Bau-bau, Provinsi Sulawesi Tenggara. Lokasi Pemeliharaan rumput laut berada pada titik koordinat $05^{\circ} 29^{\prime}$ $16,20^{\prime \prime}$ LS - $122^{\circ} 33^{\prime} 44,35^{\prime \prime}$ BT, dan pengamatan sampel kualitas air dilakukan di Lokasi penelitian. 
Media Akuatika : Jurnal Ilmiah Jurusan Budidaya Perairan. 2021. 6(4): 154-165.

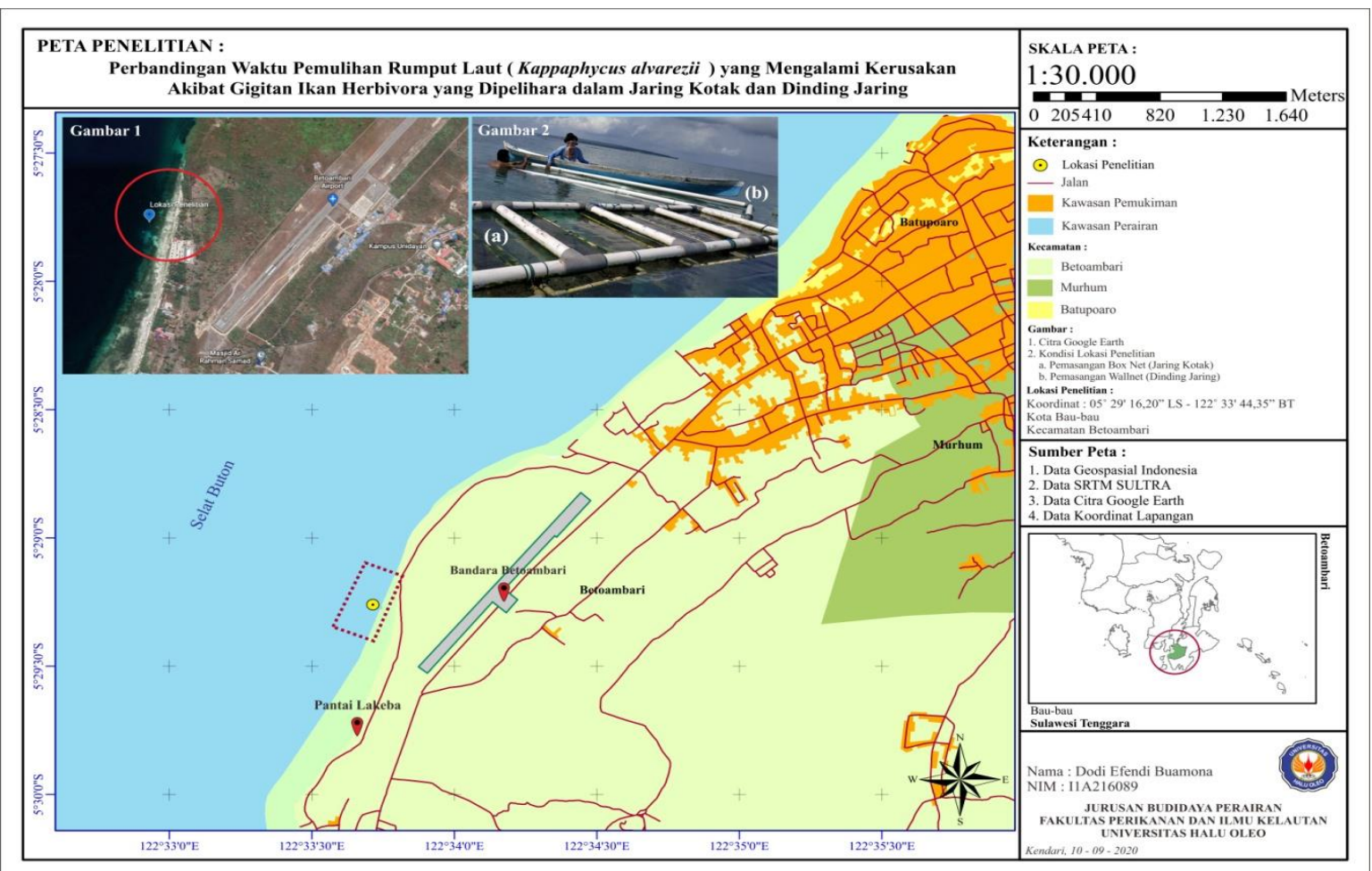

Gambar 1. Peta lokasi penelitian perbandingan waktupemulihan rumput laut $K$. alvarezii yang mengalami kerusakan akibat gigitan ikan herbivora yang dipelihara dalam jaring kotak dan dinding jaring.

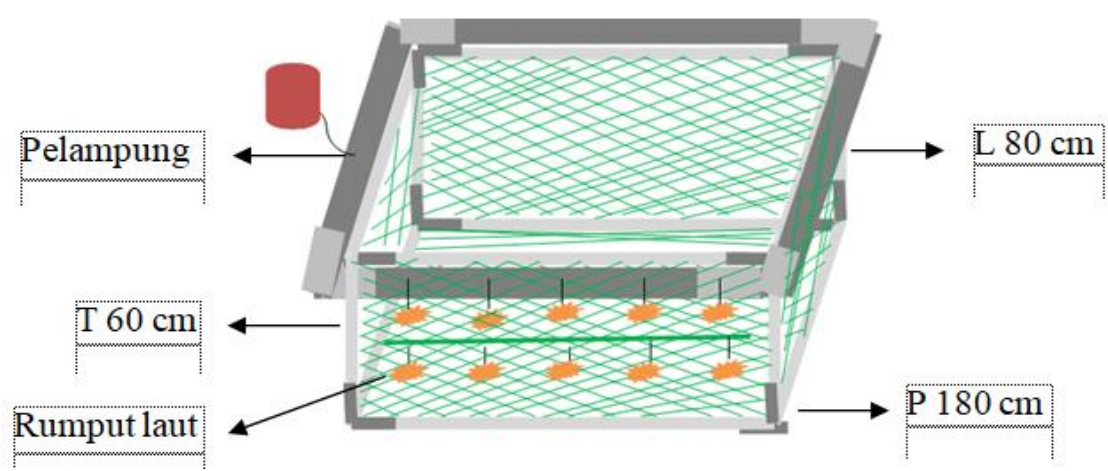

Gambar 2. Jaring Kotak

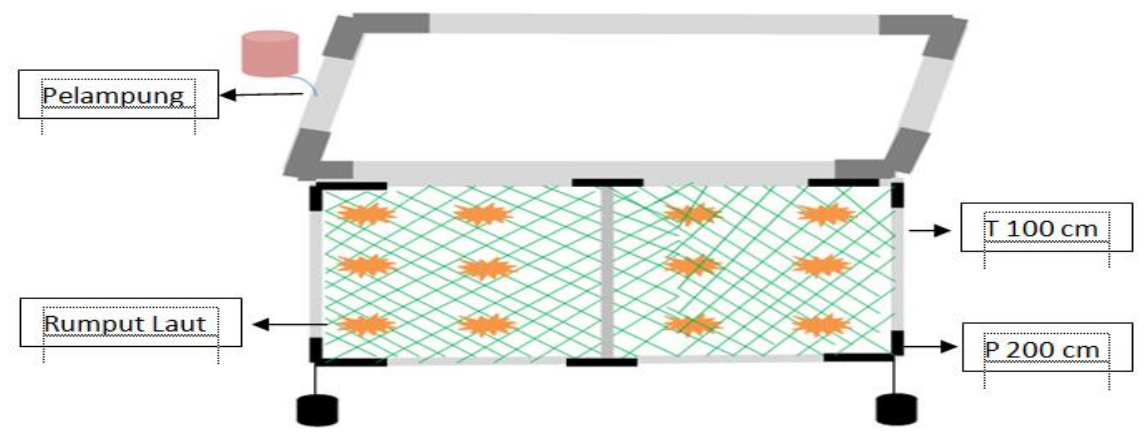

Gambar 3. Dinding Jaring 


\section{Persiapan Media Budidaya}

Media yang digunakan dalam penelitian ini berupa jaring kotak (terproteksi) dan dinding jaring (tidak terproteksi). Jaring kotak merupakan wadah budidaya yang membentuk kantung persegi empat memanjang rangka rakit terbuat dari pipa paralon berukuran 1 inci dengan jaring terbuat dari bahan nilon dengan ukuran 0,5 inci. berukuran $180 \times 80 \times 60 \mathrm{~cm}$ (Gambar 2).

Dinding jaring terbuat dari jaring yang berasal dari tali multivalen dengan meshsize 1 $1 / 2 \mathrm{~cm}$. Dinding jaring berbentuk persegi panjang dan vertikal yang menyerupai dinding. Setiap sisi dinding menggunakan pipa paralon 2 inch sebanyak 7 batang dengan panjang pipa masing-masing $180 \mathrm{~cm}$ dibutuhkan sebanyak 6 sambungan L 2 inch untuk menyambungkan pipa satu dan yang lainnya. Jaring dipasang pada sisi pipa paralon lalu diikat menggunakan tali penguat (Gambar 3).

\section{Persiapan dan Penebaran Bibit Rumput Laut}

Bibit berasal dari petani rumput laut di Perairan Pantai Lakeba, Kota Bau-Bau, Sulawesi Tenggara. Bibit rumput laut yang disiapkan adalah bibit yang telah dipelihara bersamaan dengan ikan baronang (Siganus sp), untuk selanjutnya thallus yang telah digigit ikan yang digunakan sebagai sampel penelitian. Kemudian bibit rumput laut dipotong menggunakan pisau dan ditimbang untuk mendapatkan berat awal bibit, ditimbang dengan berat awal 20 gram, lalu diikat sebanyak 10 thallus pada media pemeliharaan/penelitian.

\section{Pemeliharaan Bibit Rumput Laut}

Pemeliharaan rumput laut dilakukan dengan wadah jaring kotak dan dinding jaring di kontrol setiap hari, pengontrolan dengan cara membersihkan wadah penelitian dan rumput laut dari lumut yang menempel dan mengamati pemuihan dengan menggunakan kamera yang disambungkan pada mikroskop digital dan mengamati thallus yang mengalami kerusakan hingga benar-benar pulih atau terbebas dari luka dan muncul thallus baru. Selain itu dalam pemeliharaan bibit rumput laut setiap 7 hari dilakukan penimbangan bobot pada sampel penelitian.

\section{Rancangan Desain Penelitian}

Penempatan tata letak wadah penelitian terdiri dari 2 perlakuan dan 10 kali ulangan. Perlakuan terdiri atas media pemeliharaan jaring kotak dan dinding jaring, ulangan adalah jumlah sampelyang diikat dan ditebar sebanyak 10 rumpun rumput laut disetiap media, berat masing-masing 20 gram yang dipelihara selama 42 hari.

\section{Variabel yang Diamati \\ Perbandingan Waktu Pemulihan Thallus K. alvarezii}

Pengamatan perubahan morfologi thallus rumput laut meliputi morfologi luka awal gigitan ikan, pemulihan luka pada thallus hingga sampai muncul thallus baru. Pengamatan dilakukan menggunakan kamera dan microscope digital menggunakan pembesaran 1000 kali. Pengamatan pemulihan thallus dilakukan setiap 2 hari sekali, dan thallus yang diamati sebanyak 10 thallus setiap media pemeliharaan.

\section{Laju Pertumbuhan Spesifik (LPS)}

Laju pertumbuhan spesifik (LPS) diukur sebanyak 6 kali, terhitung dari awal penelitian hingga panen yaitu pemeliharaan selama 42 hari. LPS dihitung berdasarkan rumus Luhan and Sollesta (2010), yaitu :

$$
\text { LPS }=\frac{\ln \mathrm{Wt}_{\mathrm{t}} \ln \mathrm{Wo}_{\mathrm{o}}}{\mathrm{T}} \times 100 \%
$$

Dimana: LPS $=$ Laju Pertumbuhan Spesifik $(\%$ hari); lnWt $=$ Berat pada akhir penelitian $(\mathrm{g})$. $\operatorname{lnWo}=$ Berat pada awal penelitian (g); $\mathrm{T}=$ jumlah hari pengamatan (hari).

\section{Parameter Kualitas Air}

Pengukuran parameter kualitas air dilakukan pada saat pengamatan pemulihan thallus rumput laut dan pertumbuhan bobot rumput laut sebanyak 7 kali dengan rentang waktu 2 hari untuk pemulihan dan 7 hari untuk pertumbuhan spesifik. Parameter fisika yang diukur adalah suhu, kecerahan dan kecepatan arus, sedangkan parameter kimia yang diukur adalah salinitas, nitrat dan fosfat.

\section{Analisis Data}

Untuk mengetahui pengaruh perlakuan yang diberikan terhadap pertumbuhan rumput 
laut pada kedua media pemeliharaan diuji dengan menggunakan uji-t (independent sampel t-test) dan analisis korelasi person terhadap laju pertumbuhan spesifik rumput laut dan parameter kualitas air, untuk memudahkan dalam menganalisis maka digunakan software statistik (SPSS versi 24) dengan taraf kepercayaan $95 \%$.

\section{HASIL}

\section{Perbandingan Waktu Pemulihan Thallus Rumput Laut}

Hasil penelitian menunjukkan bahwa media pemeliharaan jaring kotak pemulihan thallus rumput laut lebih cepat yaitu 11 hari masa pemeliharaan dibandingkan media pemeliharaan dinding jaring pemulihan thallus rumput laut yaitu 15 hari masa pemeliharaan (Gambar 4). Selanjutnya proses pemulihan thallus rumput laut k.alvarezii dapat dilihat dari perubahan morfologinya (Gambar 5 dan 6).

\section{Laju Pertumbuhan Spesifik (LPS)}

Laju pertumbuhan Spesifik (LPS) dengan berat awal rumput laut masing-masing bobot 20 gram. Pertumbuhan tertinggi pada pekan pertama yaitu nilai rata-rata 7,00\%/pekan dan yang terendah pekan keenam yaitu nilai rata-rata 3,13\%/pekan, yang dipelihara pada media pemeliharaan berupa jaring kotak dan laju pertumbuhan tertinggi pada media pemeliharaan berupa dinding jaring terjadi pada pekan pertama dengan nilai rata-rata $6,61 \% /$ pekan dan terendah dengan nilai ratarata $2,95 \% /$ pekan.

Berdasarkan hasil uji $\mathrm{T}$ menunjukkan bahwa perlakuan jaring kotak dan dinding jaring memberikan pengaruh yang berbeda nyata terhadap laju pertumbuhan spesifik $K$. alvarezii yaitu jaring kotak sebesar 0,033 dan dinding jaring sebesar 0,034 nilai tersebut lebih $<0,05$.

\section{Parameter Kualitas Air}

Hasil pengukuran parameter kualitas air di lokasi penelitian terdiri dari suhu, salinitas, $\mathrm{pH}$, kecepatan arus, kecerahan, kedalaman, nitrat $\left(\mathrm{NO}_{3}\right)$ dan fosfat $\left(\mathrm{PO}_{4}\right)$ dapat dilihat pada Tabel 1. Sedangkan hubungan antara laju pertumbuhan spesifik rumput laut dan kualitas air disajikan pada Tabel 2 .

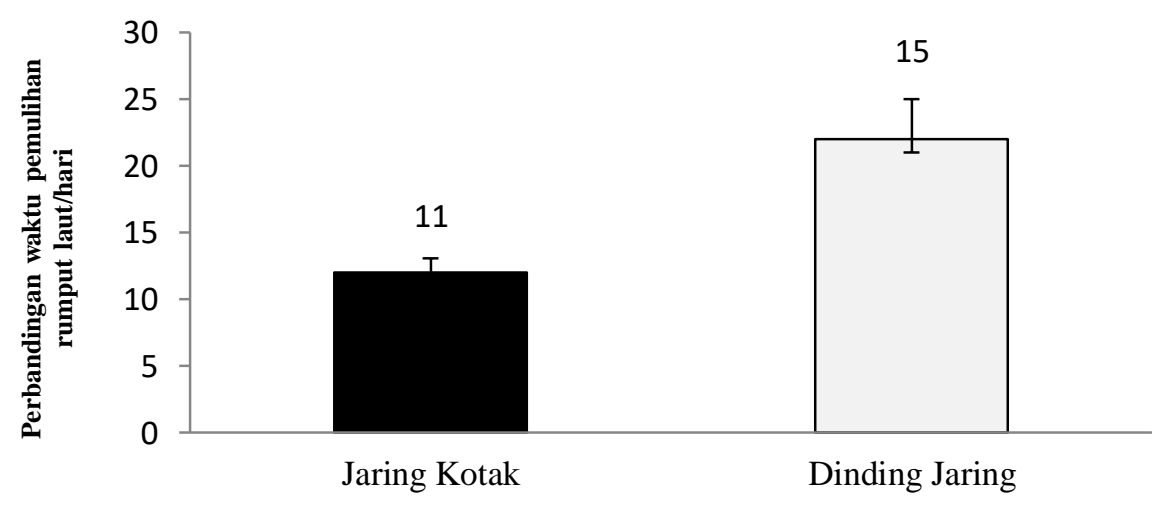

Gambar 4. Histogram perbandingan waktu pemulihan thallus rumput laut $K$. alvarezii.

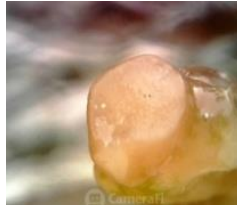

Hari ke-0

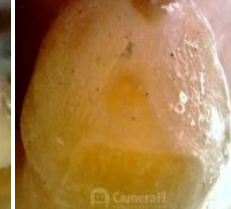

Hari ke-2

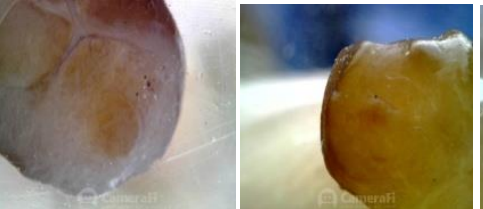

Hari ke-4 Hari ke-6

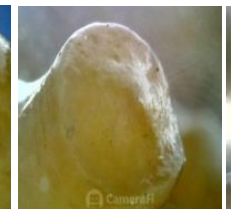

Hari ke-8

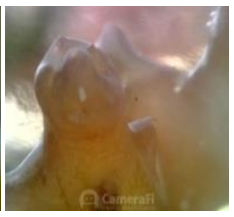

Hari ke-10-11

Gambar 5. Proses peemulihan thallus rumput laut k.alvarezii pada media pemeliharaan jaring kotak. 


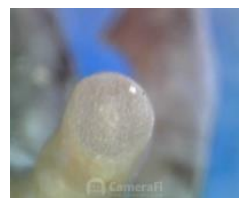

Hari ke-0

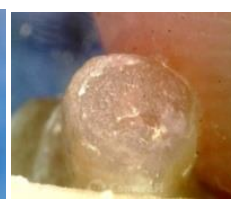

Hari ke-2

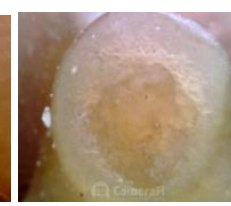

Hari ke-4

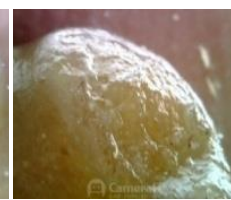

Hari ke-6

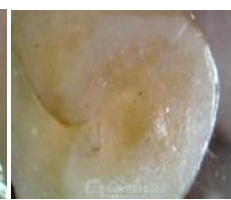

Hari ke-8

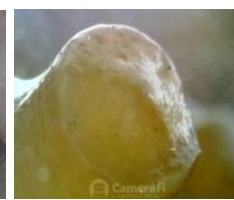

Hari ke-10

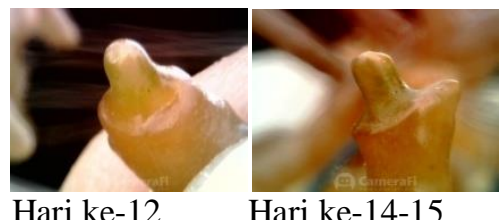

Gambar 6. Proses peemulihan thallus rumput laut k.alvarezii pada media pemeliharaan dinding jaring.

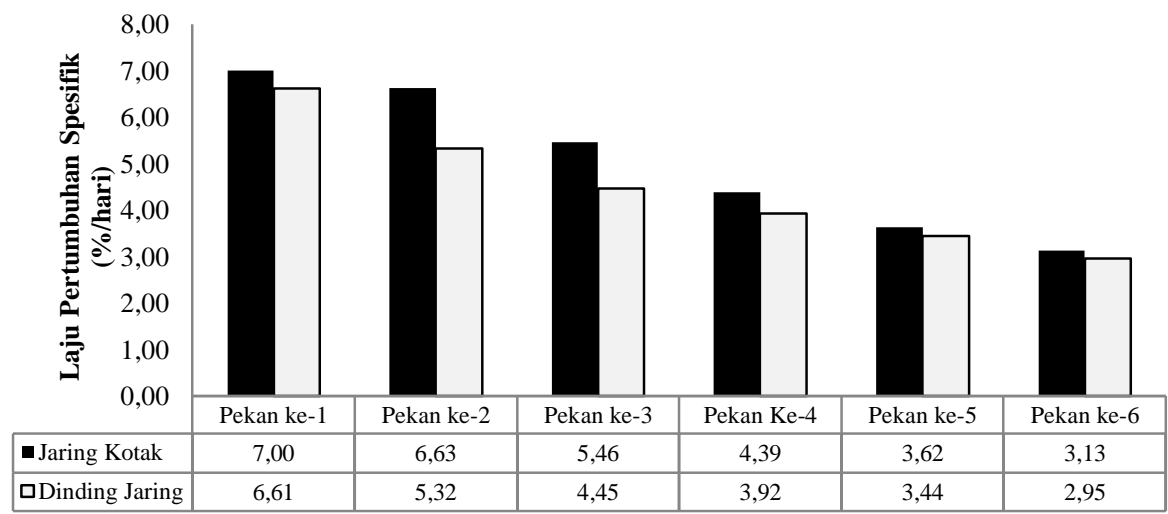

Gambar 7. Histogram laju pertumbuhan rumput laut $K$. alvarezii dengan pemeliharaan jaring kotak dan dinding jarring.

Tabel 1. Hasil pengamatan parameter kualitas air yang saat penelitian

\begin{tabular}{|c|c|c|c|c|c|c|c|}
\hline \multirow[b]{2}{*}{ Parameter } & \multicolumn{6}{|c|}{ Hari Pengamatan } & \multirow{2}{*}{ Pembanding } \\
\hline & $\mathrm{Ke}-7$ & Ke-14 & $\mathrm{Ke}-21$ & $\mathrm{Ke}-28$ & $\mathrm{Ke}-35$ & $\mathrm{Ke}-42$ & \\
\hline Suhu $\left({ }^{\circ} \mathrm{C}\right)$ & 28 & 29 & 28 & 29 & 29 & 30 & $27-32{ }^{\circ} \mathrm{C}$ (Anton, 2017) \\
\hline Salinitas (ppt) & 34 & 34 & 34 & 34 & 32 & 34 & $\begin{array}{l}\text { 30-34 ppt (Julizar } d k k . \text {, } \\
\text { 2018) }\end{array}$ \\
\hline $\mathrm{pH}(\mathrm{ppm})$ & 7,82 & 7,31 & 7,47 & 7,50 & 7,61 & 7,34 & 7-8 (Dwi dkk., 2015) \\
\hline Kedalaman (m) & 5 & 5 & 5 & 5 & 5 & 5 & $5 \mathrm{~m}$ (Astriawana, 2010) \\
\hline Kecerahan (\%) & 100 & 100 & 100 & 100 & 100 & 100 & $\begin{array}{l}\text { 100\% (Risnawati } d k k ., \\
2018)\end{array}$ \\
\hline $\begin{array}{l}\text { Kecepatan Arus } \\
(\mathrm{m} / \mathrm{s})\end{array}$ & 0,11 & 0,13 & 0,14 & 0,13 & 0,14 & 0,18 & $\begin{array}{l}0,01-0,33 \mathrm{~m} / \mathrm{s} \\
\text { (Hutabarat } d k k ., 2015 \text { ) }\end{array}$ \\
\hline Nitrat (mg/l) & 0,2 & 0,06 & 0,04 & 0,09 & 0,06 & 0,04 & $\begin{array}{l}0,1-0,7 \text { (Cokrowati } d k k \text {, } \\
2018 \text { ) }\end{array}$ \\
\hline Fosfat (mg/l) & 0,0040 & 0,0040 & 0,0030 & 0,0020 & 0,0030 & 0,0030 & $\begin{array}{l}\text { 0,02-1,4 (Bagus } d k k ., \\
2015)\end{array}$ \\
\hline
\end{tabular}

Tabel 2. Hasil analisis hubungan laju pertumbuhan spesifik rumput laut dan kualitas air yang diukur saat penelitian.

\begin{tabular}{cccccccc}
\hline LPS & Uji & Salinitas & Suhu & $\mathrm{pH}$ & Arus & Nitrat & Fosfat \\
\hline Jaring Kotak & Korelasi person & 0.437 & -0.717 & 0.309 & -0.785 & 0.590 & 0.702 \\
Dinding Jaring & Korelasi person & 0.369 & -0.726 & 0.520 & $-0.826^{*}$ & 0.778 & 0.706 \\
\hline
\end{tabular}

*correlation is significant at the 0.05 level (2-tailed). 


\section{PEMBAHASAN}

\section{Waktu Pemulihan Rumput Laut}

Pemulihan thallus merupakan proses penyembuhan luka thallus yang mengalami kerusakan dari awal luka hingga sembuh serta menyamai thallus aslinya dalam jangka waktu tertentu. Hasil pengamatan selama pemeliharaan menunjukkan tingkatan pemulihan rumput laut $K$. alvarezii yang dipelihara pada jaring kotak pemulihannya lebih cepat yaitu 11 hari masa pemeliharaan. Sebaliknya pada dinding jaring pemulihannya lebih lambat yaitu 15 hari masa pemeliharaan. Hal ini menunjukkan rumput laut yang dipelihara pada kedua wadah memiliki perbandingan waktu pemulihan. Pemulihan thallus diawali dengan berkurangnya lendir pada bekas gigitan ikan, bagian eksplan berwarna kuning kecoklatan, terdapat tonjolan kecil pada bagian tengah eksplan thallus, tonjolan menjadi semakin nampak dan menyerupai thallus aslinya. Hal ini salah satunya dipengaruhi oleh penggunaan media pemeliharaan. Mulyaningrum dkk., (2012) menambahkan bahwa thallus terbentuk pada bagian tengah (medulla), dan lapisan kortikal. Thallus berwarna coklat tua, dan terdiri dari filamen yang berasal dari pembelahan sel, yang dihasilkan dari respon sebagai luka permukaan thallus.

Menurut Mizuta dkk., (2002) menyatakan bahwa pemulihan thallus dipengaruhi oleh ketersediaan unsur hara, fitohormon yang dimiliki oleh rumput laut dan mutu air. Namun pada kondisi tertentu, kerusakan thallus tidak mengalami pemulihan, melainkan menjadi lebih rentan untuk terinfeksi penyakit, misalnya penyakit keputihan (ice-ice disease) (Tolanamy, $d k k$., 2017). Menurut Tokan (2015), pada hasil penelitiannya menunjukan bahwa rumput laut mampu menimbulkan efek antimikroba terhadap bakteri yang diisolasi dari rumput laut yang terserang oleh penyakit ice-ice. Selanjutnya $K$. alvarezii juga memproduksi antimikroba untuk melindungi dirinya dari serangan penyakit ice-ice.

Hasil penelitian menunjukkan bahwa tunas baru pada bekas luka nampak pada umur 11-15 hari masa pemeliharaan. Perihal ini salah satunya dipengaruhi oleh pemakaian media pemeliharaan, pada media jaring kotak thallus terlindungi dari hama seperti ikan herbivora, kotoran serta epifit sehingga thallus bisa membetulkan sel-sel yang rusak melalui proses fotosintesis dengan baik tanpa kendala dari hama tersebut. Sebaliknya pada media dinding jaring thallus tidak terlindungi dari hama sehingga memberi peluang hama dalam merusak thallus rumput laut, sebab tidak terproteksi sehingga proses fotosintesis berlangsung kurang baik. Hasil penelitian Mulyaningrum $d k k$., (2013) yaitu tunas mulai muncul pada usia pemeliharaan 9-15 hari. Hasil penelitian Hayashi $d k k$., (2008) bahwa kemunculan thallus baru $K$. alvarezii masingmasing sesudah 15 dan 16 hari masa pemeliharaan. Hal ini didukung oleh Mukhlis $d k k$., (2016) bahwa thallus mulai berkembang sesudah 2 minggu pemeliharaan, dimulai dengan terdapatnya bercak kecil tengah eksplan thallus serta perkembangan tunas baru ditandai dengan terdapatnya bercak coklat kehijauan segar disekitar permukaan eksplan. Bercak tersebut ialah bakal tunas baru lewat pertumbuhan vegetatif (fase vegetatif). Reddy $d k k$., (2007) dalam penelitiannya kemunculan thallus baru berlangsung pada masa pemeliharaan 10 hari.

\section{Laju Pertumbuhan Spesifik}

Pertumbuhan dan kesehatan thallus sangat menentukan kandungan karagenan rumput laut (Patadjai $d k k$., 2019), maka sangat penting untuk memberi proteksi pada wadah pemeliharaan. Hal ini sesuai dengan pernyataan Kasim, (2019) bahwa media pemeliharaan yang dapat melindungi rumput laut dari serangan ikan herbivora yaitu media yang terproteksi seperti jaring kotak, vertinet, horinet, basket net,dan rakit apung. Hasil penelitian membuktikan bahwa perlakuan yang digunakan memberikan pengaruh yang berbeda nyata, $(\mathrm{P}<0,05)$ terhadap laju pertumbuhan spesifik rumput laut $K$. alvarezii dengan berat bibit awal yang sama 20 gram. Berdasarkan grafik linear hasil penelitian pertumbuhan spesifik rumput laut dari kedua perlakuanyaitu jaring kotak diperoleh nilai rata-rata pada pekan keenam ialah 3,13\%/pekan dan dinding jaring diperoleh nilai rata-rata pada pekan keenam ialah 2,95\%/pekan. Hasil penelitian bisa dilihat pada grafik (LPS) rumput laut setiap pekan menurun. Perihal ini salah satunya dipengaruhi oleh pemakaian wadah pemeliharaan, pada 
jaring kotak thallus terlindungi dari hama ikan herbivora, kotoran serta epifit sehingga thallus tidak mengalami kendala dari hama tersebut serta thallus bisa melakukan proses fotosintesis dengan baik. Sebaliknya pada dinding jaring thallus tidak terlindungi dari hama penempel semacam lumpur, kotoran, epifit serta ikan herbivora, sebab tidak terlindungi sehingga proses fotosintesis berlangsung kurang baik. Selain telah berlangsung persaingan dalam mendapatkan unsur hara serta penyerapan cahaya matahari dalam pertumbuhan rumput laut $K$. alvarezii yang mengakibatkan pertumbuhan rumput laut alami penurunan.

Hasil pengamatan sepanjang pemeliharaan laju pertumbuhan berat rumput laut $K$. alvarezii dari pekan awal sampai pekan keenam, laju pertumbuhan paling tinggi ada pada pekan pertama serta mulai menurun pada pekan kedua hingga pekan keenam. Hal ini diprediksi ada kaitannya dengan fase perkembangan tumbuhan serta kesuburan tumbuhan. Tidak hanya itu, menurunnya laju pertumbuhan spesifik disebabkan adanya persaingan dalam perolehan unsur hara ataupun nutrien, bersamaan dengan pertambahan umur pemeliharaan rumput laut mengakibatkan terjadinya persaingan dalam mendapatkan unsur hara serta penyerapan cahaya matahari dalam proses fotosintesis, sehingga laju pertumbuhan rumput laut terus menjadi menurun tiap pekannya. Menurut Nursyahran dan Reskiati, (2013) bahwa pada pekan pertama ialah fase terbentuknya pertumbuhan vegetatif, dimana tumbuhan melaksanakan perkembangan sel-sel jaringan dewasa sehingga didapatkan perkembangan berat terus menjadi lebih besar. Mutalib dan Adi, (2018) menerangkan menurunnya laju pertumbuhan spesifik disebabkan rendahnya tingkat perkembangan yakni terdapatnya peningkatan bobot thallus yang lebih rendah.

Laju pertumbuhan rumput laut $K$. alvarezii bersumber pada perlakuan wadah yang digunakan ialah jaring kotak dan dinding jaring dengan bobot awal rumput laut yang sama di perairan pantai Lakeba Kota Bau-Bau memperlihatkan pertumbuhan terbaik terjadi pada perlakuan jaring kotak hasil yang diperoleh pada pekan keenam yaitu 3,13\% dan dinding jarringhasil yang diperoleh pada pekan keenam yaitu 2,95\%. Pertumbuhan spesifik rumput laut dengan hasil tersebut bisa dikatakan bahwa perkembangan rumput laut termasuk baik. Hal ini diperkuat dengan pernyataan Ariyati $d k k$., (2015) dimana pertumbuhan spesifik yang lumayan baik untuk rumput laut yaitu 2,03\%-2,36\%. Menurut Dwi $d k k .$, (2015) dalam usaha budidaya rumput laut laju pertumbuhan spesifik yang dikatakan baik serta menguntungkan ialah 2,36\%. Menurut Julizar dkk., (2018) bahwa laju pertumbuhan yang menguntungkan yaitu di atas $3 \%$. Patadjai $d k k$., (2019) dalam penelitiannya menggunakan perendaman ekstrak lantana diperoleh pertumbuhan tertinggi $6,43 \%$ dan yang tanpa ekstrak lantana pertumbuhan tertinggi 5.86\%.

\section{Parameter Kualitas Air}

Berdasarkan hasil pengukuran suhu yang diperoleh pada lokasi penelitian ini ialah ratarata berkisar antara $28-30^{\circ} \mathrm{C}$. Hasil pengamatan membuktikan kecenderungan kenaikan temperatur mulai hari awal hingga hari ke-42 relatif normal dengan kenaikan yang tidak sangat drastis. Menurut Arjuni dkk., (2015) bahwa suhu yang baik untuk budidaya rumput laut jenis $K$. alvarezii berkisar antara $20-28^{\circ} \mathrm{C}$.

Pengukuran salinitas yang diperoleh selama penelitian berkisar anatara 32-34 ppt. Kisaran salinitas ini masih terkategori baik untuk pertumbuhan rumput laut $K$. alvarezii. Salinitas yang tinggi akan berpengaruh terhadap pertumbuhan dan daya tahan terhadap penyakit. Menurut Choi dkk., (2010) rumput laut hendak mengalami pertumbuhan yang lambat, apabila salinitas sangat rendah (kurang $15 \mathrm{ppt}$ ) ataupun sangat besar (lebih dari $35 \mathrm{ppt}$ ) dari kisaran salinitas yang cocok dengan ketentuan hidupnya sampai jangka waktu tertentu.

Pengukuran $\mathrm{pH}$ diperoleh selama penelitian berkisar antara 7,31-7,82 yang terkategori masih dalam kisaran yang bisa ditoleransi oleh rumput laut. Menurut Atmanisa $d k k$., (2020). Berdasarkan hasil penelitiannya yaitu nilai $\mathrm{pH}$ 7,6-7,7 memperlihatkan zona pemanfaatan budidaya rumput laut berada dalam kisaran yang mendukung untuk dilakukannya budidaya rumput laut.

Pengukuran kedalaman perairan pada saat penelitian berkisar antara $3 \mathrm{~m}$ (surut terendah) serta $5 \mathrm{~m}$ (pasang paling tinggi). Kisaran kedalaman perairan tersebut masih dinyatakan layak bagi pertumbuhan rumput laut $K$. alvarezii. Hal ini sesuai dengan 
pernyataan Julizar dkk., (2018) budidaya rumput laut $K$. alvarezii dengan kedalaman yang berkisar antara $3 \mathrm{~m}$ (surut terendah) serta $8 \mathrm{~m}$ (pasang paling tinggi) dikategorikan baik bagi pertumbuhan rumput laut $K$. alvarezii.

Pengukuran kecerahan selama penelitian ialah pada kisaran $100 \%$. Kecerahan perairan pantai Lakeba diketahui bahwa sinar matahari bisa menembus sampai kedasar perairan. Hasil penelitian membuktikan bahwa keadaan diperairan pantai Lakeba kota Bau-Bau sangat baik untuk perkembangan rumput laut. Sama halnya dengan penelitian Yudiastuti, (2017) kecerahan yang diperoleh yaitu 100\% masih dikategorikan dalam kelayakan aktivitas usaha budidaya rumput laut. Menurut Hayashi $d k k$. (2007) bahwa kecerahan perairan lokasi yang cocok untuk budidaya rumput laut $>2$ meter. Semakin cerah suatu perairan berarti partikelpartikel lumpur yang kemungkinan terdapat dalam kolom air semakin sedikit, memungkinkan cahaya yang besar akan menunjang proses fotosintesis akan menyebabkan proses metabolisme sehingga merangsang rumput laut untuk menyerap unsur hara yang lebih banyak.

Pengukuran kecepatan arus diperoleh selama penelitian $0,11-0,18 \mathrm{~m} / \mathrm{s}$, berdasarkan analisis kecepatan arus maka perairan laut pantai Lakeba masih baik digunakan untuk budidaya rumput laut $K$. alvarezii namun kecepatan arus tersebut masih bisa menyuplai unsur hara walaupun dengan jumlah yang sedikit. Susilowati $d k k$., (2012) menyatakan bahwa arus sangat mempengaruhi untuk rumput laut dalam pengambilan nutrien serta membawa unsur makanan. Nursidi $d k k$., (2017) menambahkan bahwa arus yang keras akan mengganggu serta membahayakan rumput laut seperti rumput laut dapat patah, robek serta terlepas dari substrat. Menurut Mudeng $d k k$., (2015) bahwa kecepatan arus yang baik untuk pertumbuhan rumput laut yaitu $0,2-0,4 \mathrm{~m} / \mathrm{s}$.

Berdasarkan hasil penelitian, kandungan Nitrat $\left(\mathrm{NO}_{3}\right)$ yang diperoleh berkisar 0,04-0,2 mg/l. Menurut Utojo dkk., (2007) bahwa kadar nitrat yang ideal untuk rumput laut berkisar antara 0,0057-0,00185 g/l. Menurut Rujiman $d k k$. , (2013) bahwa konsentrasi nitrat perairan yang baik untuk pertumbuhan rumput laut adalah 0,0071-0,0169 mg/l. Kondisi perairan yang mempunyai konsentrasi nitrat yang tinggi, umumnya dipengaruhi oleh kegiatan yang ada didaratan yang dapat menghasilkan sampah organik dari rumah tangga.

Berdasarkan hasil penelitian, kandungan fosfat $\left(\mathrm{PO}_{4}\right)$ yang diperoleh berkisar antara 0,0020-0,0040 mg/l. Hal ini sesuai dengan hasil yang diperoleh oleh Julizar $d k k$., (2018) yaitu 0,0007-0,0040 mg/l. Data ini masih cukup baik untuk pertumbuhan rumput laut. Hal ini sesuai dengan pendapat Patty $d k k$., (2015) bahwa kisaran fosfat 0,0021-0,050 lumayan subur untuk pertumbuhan rumput laut.

\section{Analisis Hubungan Pertumbuhan Spesifik Rumput Laut K.alvarezii dan Kualitas Air}

Hasil analisis korelasi person pada Tabel 2 menunjukkan bahwa parameter kualitas air yang tidak berpengaruh secara signifikan pada bibit rumput laut $K$. alvarezzi yang dipelihara dalam media jaring kotak yaitu salinitas, suhu, $\mathrm{pH}$, nitrat, fosfat, dan kecepatan arus. Sedangkan pada media dinding jaring yaitu salinitas, suhu, $\mathrm{pH}$, nitrat, fosfat, namun semua parameter ini tetap masih dapat mendukung pertumbuhan rumput laut tetapi pertumbuhannya lumayan lambat namun semua bibit rumput laut tetap tumbuh dengan baik. Hal didukung oleh pernyataan Julizar $d k k$, (2018) bahwa proses budidaya rumput laut sangat dipengaruhi oleh kualitas air dalam menunjang pertumbuhan rumput laut, sehingga kualitas perairan yang baik dan sesuai sangat diperlukan untuk keberhasilan budidaya rumput laut.

Kecepatan arus memberikan pengaruh signifikan pada pertumbuhan bibit rumput laut $K$. alvarezzi yang dipelihara dalam media dinding jaring (Tabel 2), dimana kita ketahui bahwa kecepatan arus merupakan salah satu parameter yang juga berperan penting dalam perolehan unsur hara bagi rumput laut dalam mendukung pertumbuhan rumput laut tersebut. Susilowati $d k k .$, (2012) menyatakan bahwa arus sangat berpengaruh bagi rumput laut dalam pengambilan nutrien dan membawa unsur makanan. Pong-Masak dkk., (2010) menambahkan bahwa Arus sangat bermanfaat dalam menyuplai dan meningkatkan difusi unsur hara kedalam jaringan tanaman serta menyebabkan fluktuasi salinitas dan suhu yang kecil. 


\section{KESIMPULAN}

Pemulihan thallus rumput laut $K$. alvarezii yang dipelihara dalam media pemeliharaan yaitu jaring kotak lebih cepat pulih yaitu 11 hari masa pemeliharaan dibandingkan dinding jaring yaitu 15 hari masa pemeliharaan.

Laju pertumbuhan spesifik (LPS) antara jaring kotak dan dinding jaring berbeda secara signifikan. Pertumbuhan rumput laut $K$. alvarezii dipengaruhi secara signifikan oleh kecepatan arus.

\section{REFERENSI}

Anton. (2017). Pertumbuhan dan Kandungan Karaginan Rumput Laut (Eucheuma) pada Spesies yang Berbeda. Jurnal Airaha. 5(2):102-109.

Ariyati, R, W., Widowati, L, L., Rejeki, S. (2015). Performa produksi rumput laut Eucheuma cottonii yang dibudidayakan menggunakan metode Long-Line vertikal dan horizontal. Prosiding Seminar Nasional Tahunan Ke V Hasil Hasil Penelitian Perikanan dan Kelautan. Fakultas Perikanan dan Ilmu Kelautan UNDIP. Semarang.

Arjuni, A., Cokrowati, N., Rusman. (2015). Pertumbuhan rumput laut Kappahycus alvarezii hasil kultur jaringan. Jurnal Biologi Tropis, 18(2):216-223. doi.org/10.29303/jbt.v18i2.740

Aslan. L. O. M. (1991). Budidaya Rumput Laut. Penerbit Kanisius. Jakarta.

Astriawana. (2010). Peran perendaman dengan air tawar dalam menekan penyakit pada budidaya rumput laut Kappaphycus alvarezii Dotty di perairan semak daun Kepulauan Seribu Jakarta. Skripsi. Institut Pertanian Bogor. Bogor.

Atmanisa, A., Mustarin, A., \& Anny, N. (2020). Analisis Kualitas Air pada Kawasan Budidaya Rumput Laut Eucheuma Cottoni di Kabupaten Jeneponto. Jurnal Pendidikan Teknologi Pertanian, 6(1), 11-22. DOI https://doi.org/10.26858/jptp.v6i1.11275

Bagus, Y. D., Saifullah., Hermawan, D. 2015. Evaluasi Kesesuaian Lokasi Pengembangan Budidaya Rumput Laut (Kappaphycus Alvarezii) di Desa Lontar, Kecamatan Tirtayasa, Kabupaten Serang.
Jurnal Perikanan dan Kelautan, 5(2):4955.

Choi, T. S., Ju. E, K., Hyoung, J. K., Young, K. K., (2010). Effect of Salinity on Growth and Nutrient Uptake of Ulva Pertusa (Chlorophyta) From an Eelgrass Bed. Algae, 25(1): 17-26. DOI. 104490/algae2010.25.1.017

Cokrowati, N., Arjuni, A., \& Rusman, R. (2018). Pertumbuhan Rumput Laut Kappaphycus alvarezii Hasil Kultur Jaringan. Jurnal Biologi Tropis, 18(2): 216-223.

DOI: org/10.29303/jbt.v18i 2.740

Doty, MS. 1985. Biotechnological and Economic Approaches to Industrial Development Based on Marine Algae in Indonesia. Jakarta.

Dwi, A. H., Rejeki, S., Wisnu, R. A. 2015. Pertumbuhan budidaya rumput laut (Eucheuma cottonii Dan Gracilaria sp.) dengan metode Long Line di perairan pantai bulu jepara. Journal of Aquaculture Management and Technology. 4(2):60-66.

Faisal, L. O., Sofyan, R. P., Yusnaini. 2013. Pertumbuhan rumput laut (Kappaphycus alvarezii) dan ikan baronang (Siganus guttatus) yang dibudidayakan bersama di keramba tancap. Jurnal Mina Laut Indonesia, 1(1):104-111.

Hayashi, L., de Peula, E, J., Chow, F. 2007. Growth rate and carragenan annalyses, in four striains of Kappaphycus alvarezii (rhodophyta, gigatinales) farmed in the subtropical waters of sao paulo state, brazil. Journal of Applies Phycology. 19(5):393-399. DOI: 10.1007/s10811-006-9135-6.

Hayashi, L., Yokoya, N. S., Kikuchi D. M., and Oliveira, E. C. 2008. Callus induction and microipropagation improved by colchicine and phytoregulators in Kappaphycus alvarezii (rhodophyta, solieriaceae). J. Appl. Phycol. 20:653659. DOI: $10.1007 / \mathrm{s} 10811-006-9135-6$

Hutabarat, S., Retna, S. W., Ruswahyuni. 2015. Pengarus Arus dan Substrat Kerapatan Rumput Laut di Perairan Pulau Pajang Sebelah Barat dan Selatan. Diponegoro. Journal Of Maquares Management Of Aquatic Resources. 4 (3): 91-98. https//doi.org/10.14710/marj.v4i3.9324. 
Julizar, S., Kurnia, A, Kasim, M. 2018. Perbandingan Laju Pertumbuhan Kappaphycus alvarezii Hasil Kultur Jaringan pada Kedalaman Berbeda yang Dipelihara pada Pakit Jaring Apung. Media Akuatika. 3(4):749-759.

Kamlasi, Y. 2008. Kajian Ekologis dan Biologi untuk Pengembangan Budidaya Rumput Laut (Eucheuma cottonii) Dikecamatan Kupang Barat Kabupaten Kupang Propinsi Nusa Tenggara T imur. Tesis. Sekolah Pascasarjana, Institut Pertanian Bogor. Bogor.

Kasim, M. 2019. Buku Panduan Alganet, Inovasi Alat Budidaya Rumput Laut. CPPBT. Lembaga Penelitian dan Pengabdian Kepada Masyarakat. Universitas Halu Oleo. Kendari.

Luhan M. R. J., Sollesta H., 2010 Growing the Reproductive Cells (carpospores) of the Seaweed, Kappaphycus striatum, in the Laboratory Until Outplanting in the Field and Maturation to Tetrasporophyte. J Appl Phycol. 22:579585. DOI: 10.1007/s10811-009-497-7

Mizuta, H., Shirakura, Y., Yasui, H. 2002. Relationship Between Phycoerythrin and Nitrogen Content in Gloiopeltis Furcata and Porphyra Yezoensis. Algae. 17(2): 89-93.

Muklis., Raihani, Z. Y., Rusaini. 2016. Pertumbuhan Eksplan Rumput Laut Kappaphycus alvarezii pada Lama Perendaman Berbeda dalam Larutan Pupuk Urea dan TSP. Simposium Nasional Ilmu Kelautan dan Perikanan III. Universitas Hasanuddin. Makassar.

Mulyaningrum, S. R. H., Nursyam, H., Risjani, Y., Parenrengi, A. 2012. Regenerasi Filamen Kalus Rumput Laut Kappaphycus alvarezii dengan Formulasi Zat Pengatur Tumbuh yang Berbeda. Jurnal Penelitian Perikanan, 1(1):52-60.

Mulyaningrum, S. R. H., Parenrengi, A., Risjani, Y., \& Nursyam, H. (2013). Formulasi auksin (indole acetic acid) dan sitokinin (kinetin, zeatin) untuk morfogenesis serta pengaruhnya terhadap pertumbuhan, sintasan dan laju regenerasi kalus rumput laut, Kappaphycus alvarezii. Jurnal Riset Akuakultur, 8(1): 31-41. DOI: http://dx.doi.org/10.15578/jra.8.1.2013.3 $1-41$

Mudeng, J. D., Magdalena, E. F. K., Abdul, R. 2015. Kondisi Lingkungan Perairan pada Lahan Budidaya Rumput Laut Kappaphycus alvarezii Di Desa Jayakarsa Kabupaten Minahasa Utara. Jurnal Budidaya Perairan. 3(1):172-186.

Munaeni, W. 2011. Pertumbuhan Dan Karaginan Beberapa Rumput Laut Kappaphycus alvarezii Dengan Warna Thallus Yang Berbeda Yang Dipelihara Pada Perairan Berkarang. (Skripsi). Budidaya Perairan, Fakultas Perikanan Dan Ilmu Kelautan, Universitas, Halu Oleo, Kendari.

Mutalib, Y., Adi, S. R. 2018. Pertumbuhan dan Kandungan Karaginan Rumput Laut Kappaphycus alvarezii pada Dosis Mikroorganisme Lokal (MOL) Buah Maja. Journal of Blue Oceanic. 2(1):1-8.

Nursidi., Mauli., Heriansah. 2017. Development of Seaweed Kappaphycus alvarezii Cultivation Through Vertical Method in the Water of Small Islands in South Sulawesi, Indonesia. AACL. Bioflux, 10(6):1428-1435.

Nursyahran., Reskiati. 2013. Peningkatan Laju Pertumbuhan thallus Rumput Laut (Kappaphycus alvarezii) yang Direndam Air Beras dengan Konsentrasi yang Berbeda. Jurnal Balik Diwa. 4(2):13-18.

Parenrengi, A., Syah, R., Suryati, E. 2010. Budidaya Rumput Laut Penghasil Karaginan (Karagenofit). Balai Riset Perikanan Budidaya Air Payau. Badan Penelitian dan Pengembangan Kelautan dan Perikanan. Kementrian Kelautan dan Perikanan. Jakarta.

Patadjai, R. S., Nur, I., Kamri, S. 2019. Use of Common Lantana (Lantana Camara Linn) Extrac to Prevent Ice-Ice and Trigger Growth Rate of the Seaweed Kappaphycus alvarezii. The 2nd International Symposium on Marine Science and Fisheries (ISMF2). IOP. Conf. Series: Earth and Enviromental Science 370(01):1-10. DOI: 10.1088/1755-1315/370/1/012026

Patty, S. I., Arfah, H., \& Abdul, M. S. (2015). Zat Hara (Fosfat, Nitrat), Oksigen Terlarut dan pH Kaitannya dengan Kesuburan Di Perairan 
Jikumerasa, Pulau Buru. Jurnal Pesisir dan Laut Tropis, 3(1):43-50. DOI:https://doi.org/10.35800/jplt.3.1. 2015.9578

Pong-Masak P.R., Andi I. J. A., Hasnawi, Andi M. P., \& Mahatma L. 2010. Analisis Kesesuaian Lahan untuk Pengembangan Budidaya Rumput Laut di Gusung Batua, Pulau Badi Kabupaten Pangkep, Sulawesi Selatan. Jurnal Riset Akuakultur,5(2): 299-316.

Reddy, CRK., Raja, G. K. K., Bhavanath, J. 2007. Callus Induction and Thallus Regeneration From Callus of Phycocolloid Yielding Seaweeds From the Indiancoast. Journal of Applied Phycology. 19(1):15-25. DOI: 10.1007/s10811-007-9205-4

Risnawati., Kasim, M., Haslianti. 2018. Studi Kualitas Air Kaitannya dengan Pertumbuhan Rumput Laut (Kappaphycus alvarezii) pada Rakit Jaring Apung di Perairan Pantai Lakeba Kota Bau-Bau Sulawesi Tenggara. Jurnal Sumber Daya Perairan. 4(2):155164.

Rujiman, L, M., Aslan, L. O. M., Sabilu, K. 2013. Pengaruh Jarak Tali Gantung dan Jarak Tanam yang Berbeda Terhadap Pertumbuhan Rumput Laut (Kappaphycus alvarezii) Strain Hijau Melalui Seleksi Klon dengan Menggunakan Metode Vertikultur (Periode I-III). Mina Laut Indonesia. 3(12):22-35.

Sarwono, J. 2009. Statistik Itu Mudah: Panduan Lengkap Untuk Belajar Komputansi Statistik Menggunakan SPSS 16. Universitas Atma Jaya Yogyakarta. Yogyakarta.

Selviani., Andriani, I. Soekandarsi, E. 2018. Studi Kebiasaan Makan Ikan Baronang (Lingkis siganus canaliculatus) Di Kepulauan Tanakeke Takalar Sulawesi Selatan. Bioma. Jurnal Biologi Makassar, 3(1):19-25.

Sitepu, F., Suwarni., Sudarwati. 2018. Kebiasaan Makanan Ikan Baronang Lingkis (siganus canaliculatus Park) Di Perairan Selat Makassar. Jurnal Pengelola Perairan,1(1):66-76.
Susilowati, T., Rejeki, S., Nurcahaya, E. D., Zulfitriani. 2012. Pengaruh Kedalaman Terhadap Pertumbuhan Rumput Laut (Eucheuma cottonii) yang Dibudidayakan dengan Metode Long Line Di Pantai Mlonggo, Kabupaten Jepara. Jurnal Saintek Perikanan. 8(1):712.

Tokan, K, M., Gufran, D, D., Mbing, M, I. 2015. Controlling of the Ice-Ice Disease on Seaweed Through Polyculture Cultivation Techniques. Asian Journal of Microbiol. Biotech. 17(1) : 7-15.

Tolanamy, E. S., Patadjai, R. S., Nur, I. 2017. Potensi Estrak Daun Tembelekan Lantana camara Sebagai Penghambat Tumbuh Bakteri pada Rumput Laut. Jurnal Sains dan Inovasi Perikanan 1(1):9-16. doi. http://dx.doi.org/10.33772/jspi.v1n1.xxx $\mathrm{X}$

Utojo, A. Mansyur, B., Pantjara, A. M., Pirzan., Hasnawati. 2007. Kondisi Lingkungan Perairan Teluk Mallasora yang Layak untuk Lokasi, Pengembangan Budidaya Rumput Laut (Eucheumas p.). Jurnal Riset Akuakultur. 2(2):243-255.

Winarno F, G., Fardiaz S, Fardiaz D. 1996. Teknologi Pengolahan Rumput Laut. Jakarta (ID). Gramedia Pustaka Utama. Jakarta.

Yudiastuti. 2017. Laju Pertumbuhan Rumput Laut Eucheuma cottonii Melalui Budidaya IMTA (Integrated Multi Trophic Aquaculture) Di Pantai Geger, Nusa Dua, Kabupaten Bandeung, bali (Skripsi). Fakultas Kelautan dan Perikanan, Universitas Udayana.

Zainuddin, F. dan Masyarul, M. R. 2018. Performa Rumput Laut Kappaphycus alvarezii dari Maumere dan Tembalang pada Budidaya Sistem Long Line. Journal of Aquaculture Science. 3(1):1728.

DOI: https://doi.org/10.31093/joas.v3i1.37 